\title{
Research on Pastoral Trilogy of George Sand
}

\author{
Jun Yu \\ Department of Foreign Languages, Zhongbei College of Nanjing Normal University, Nanjing, China \\ Email: justineyj@126.com
}

How to cite this paper: Yu, J. (2019) Research on Pastoral Trilogy of George Sand. Open Journal of Social Sciences, 7, 146-154. https://doi.org/10.4236/jss.2019.79011

Received: August 25, 2019

Accepted: September 16, 2019

Published: September 19, 2019

Copyright $\odot 2019$ by author(s) and Scientific Research Publishing Inc. This work is licensed under the Creative Commons Attribution International License (CC BY 4.0).

http://creativecommons.org/licenses/by/4.0/

\begin{abstract}
This paper analyzes George Sand's famous pastoral trilogy under five aspects. First, affection for the countryside. She's excellent at describing the countryside, from the great scene of nature to the details of peasants' daily life. Second, optimistic romanticism. Her joyful words and the comparison with authors like Chateaubriand and Musset show her optimistic romanticism. Third, feminism. There's a sprout of feminism growing in her pastoral trilogy. It encourages women to pursue their happiness without considering the hindrances of traditional and ethical opinions. Fourth, love. Love crosses the stories in George Sand's pastoral trilogy, creates a utopian world in her heart, where everyone loves each other and lives happily. Fifth, democracy. George Sand expresses her love and hatred by drawing, with a democratic color, a sharp contrast between the virtue of honest peasants and the vice of corrupt bourgeois.
\end{abstract}

\section{Keywords}

George Sand, Pastoral Trilogy, Countryside, Rustic Novel

\section{Introduction}

George Sand, pseudonym of Amantine Aurore Lucile Dupin, is a French novelist. She was born in 1804 and died in 1876. She's one of the most prolific writers in the $19^{\text {th }}$ century, with hundreds of various works in which she defends women and fights the prejudices of conservative society. She had a great friendship with Victor Hugo by correspondence but these two great personalities have never met. In the speech at the funeral of George Sand, Victor Hugo eulogized her part in French literature as one of the jewels of their century and their country. According to Hugo, George Sand has a big heart like Barbès, a great spirit like Balzac, a great soul like Lamartine, she has a unique place in their time, others are great men, and she is the great woman. Historically, literary creation or criticism was considered a profession only for men. There's not even a feminine gender of 
French word like "écrivain" (writer) or "auteur" (author). Being a woman, George Sand opened a path among male writers and finally left her name to posterity. George Sand's writing style is different from the power of Victor Hugo, the passion of Mérimée, the legend of Alexandre Dumas, even the melancholy of Jean-Jacques Rousseau, the precursor of romanticism, although the latter had a great influence on her writing.

Since the Reform and Opening-up in the 70s, lots of foreign books have been translated and introduced in China. At that time, Victor Hugo and his masterpiece Notre Dame de Paris or Les Trois Mousquetaires of Alexandre Dumas were rather familiar to Chinese readers, but perhaps few people knew George Sand, one of the brightest stars in the $19^{\text {th }}$ century French literature. Now the situation is better than before; the anthology of her main works can be easily found in libraries or bookstores. Among these works, her three rustic novels, as known as the pastoral trilogy of George Sand, are most widely read: La mare au diable, La petite Fadette and François le Champi.

Talking about George Sand's pastoral trilogy, there're some keywords that can't be neglected. The first keyword is "countryside". Since childhood, George Sand had a fondness for the countryside because of the influence of Jean-Jacques Rousseau's thoughts and her childhood life at Nohant. She's excellent at describing the countryside, from the great scene of nature to the details of peasants' daily life; the second keyword is "romanticism". By reading the joyful words of George Sand and the comparison with authors like Chateaubriand and Musset, her optimistic romanticism can be strongly felt by readers; the third keyword is "feminism". There's a sprout of feminism growing in her pastoral trilogy. She encourages women to pursue their happiness, without considering the hindrances of traditional and ethical opinions. This is considerably earlier than Simone de Beauvoir, the well-known feminist in the $20^{\text {th }}$ century; another keyword is "love". Love crosses stories in George Sand's pastoral trilogy, creates a utopian world, where everyone loves each other and lives happily; "democracy" is also reflected in her pastoral trilogy. George Sand draws a sharp contrast between the virtue of honest peasants and the vice of corrupt bourgeois, showing her sympathy for the poor. In the following passages, these five aspects of George Sand's pastoral trilogy will be analyzed in detail.

\section{Affection for the Countryside}

In these three novels, George Sand paints the landscape of nature and life in the countryside. She pays attention to the fate of peasants. In her pastoral trilogy, peasants become the protagonist [1]. The description of the picturesque landscape of nature, the pure heart that city life has not corrupted, the simple and lively language of peasants, has expressed her affection for countryside, for nature, for farmers, etc.

\subsection{The Return to Nature}

George Sand lived in the countryside when she was little. The fresh air, the blue 
sky and the working peasants gave her a good impression. After, she was influenced by the thoughts of J.-J. Rousseau, who launched the slogan "retourner à la nature" (return to nature), she became a writer who had a lot of affection for the nature and the rural life. For example, in La mare au diable, George Sand praised nature like a mother. "Nature is eternally young, beautiful and generous. She pours poetry and beauty to all beings, to all plants, which are allowed to develop at will. She has the secret of happiness, and no one knew how to take it away from her." [2] Her affection for the nature and the rural life is reflected in her pastoral trilogy by praising the picturesque landscape of the countryside, the atmosphere of peace, and the harmony of human with nature.

As a romantic writer in the 19th century, George Sand inherited Rousseau's thoughts: to love nature, to admire honest and simple humanity. But it should be noted that, for Rousseau and George Sand, even if facing the same landscape of nature, their style of expressing romanticism is different. Rousseau's style is inclined to sorrow, while that of George Sand is rather happy and easy.

\subsection{The Aspiration to Rural Life}

In George Sand's rustic novels, there's always a peaceful village and honest peasants and often a harmonious family relationship. For example, in La mare au diable, Germain's father-in-law persuades him to remarry after the death of his wife. The dialogue between these two people shows a strong affection of the stepfather for the son-in-law, and also a good and ideal family relationship. According to George Sand, the village is a pure place far from the noisy city, truly a paradise on earth; the peasants are honest workers far from the vices of the bourgeoisie, like angels descending into the world. At the same time as she paints these pretty pictures, readers are led little by little to a harmonious world, they can feel the peace, the simplicity, the freedom of rural life. They can't help but beginning to aspire to this kind of life style.

\subsection{The Simple and Lively Language of Peasants}

During her childhood, George Sand lived in the countryside of Berry, south of Paris. So, the habits and customs in Berry often serve as her writing materials. In her pastoral trilogy, the words of characters are very simple, and there're many dialects and spoken languages. George Sand is very sensitive to the language of the countryside. She's also very good at searching and discovering the lively and interesting words of peasants.

The characteristic of George Sand's pastoral trilogy shows itself in two parts. Firstly, most stories in those three rustic novels are based on dialogues. The author lets the characters speak, thus reinforcing the objectivity and readability of novels. For example, there're many words belonging to the oral language, such as "tiens", "eh bien", "par exemple", "ah oui", "ah", "eh", "bah", etc; secondly, the author uses simple, lively and funny words. These words come from people, there're also some dialects, the sentences are short, the grammar is simple, it's close to life in the countryside. 
George Sand is very good at capturing the simple and lively words of peasants. Here is a well-known folk song in La mare au diable, the lyrics of this folk song are simple as spoken language, readers can easily feel the joy and humor of peasants during the wedding. It's called Le dit de corbeille de mariage:

"Ouvrez la porte, ouvrez

Marie ma mignonne

Pons de beaux cadeaux à vous présenter

Hélas! Ma mie, laissez-nous entrer

Mon père est en chagrin, ma mère en grande tristesse

Et moi je suis fille de tros grand merci

Pour ouvrir ma porte à cette heure ici

fons un beau mouchoir à vous présenter

Un beau mari à vous présenter

Ouvrez la porte, ouvrez

Marie ma mignonne

Cest un beau mari qui vient vous chercher

Allons, ma mie laissons-les entrer." [2]

\section{Optimistic Romanticism}

The heroes of George Sand's pastoral trilogy are honest and caring. After experiencing many setbacks, they always end up with a happy-ending. This is the optimistic romanticism of George Sand.

Since the birth of Romanticism, a distinction has been made between optimistic and pessimistic romanticism based on a different attitude towards truth. The works of pessimistic romanticism present a style of loneliness, melancholy, and decadence. Tortured by an indescribable pain, the characters in these works often push things to dark side. In the end, the narrative often has a tragic color: to commit suicide or to flee from society. Chateaubriand and Musset are the writers representing pessimistic romanticism. On the contrary, there's always a soft and light atmosphere in the works of optimistic romanticism. The characters never lose their courage and confidence to overcome the difficulties that block their path to happiness. George Sand is one of the writers of optimistic romanticism. In her pastoral trilogy, although the characters face a lot of obstacles, they can always end up with a happy-ending. It's exactly different from the works of pessimistic romantic writers, like Chateaubriand, Vigny, Musset.

During her life at the convent, George Sand had taken a great interest in the works of Chateaubriand. But after she began to walk the path of literature, she did not blindly imitate his tendency to pessimistic romanticism. On the contrary, she had the audacity to go against the current of the time, and clearly expressed an optimistic romanticism. In the eyes of George Sand, although life is full of setbacks, it will be beautiful if one does not lose the courage to pursue happiness and to refuse social prejudices. These optimistic thoughts are reflected in her pastoral trilogy. For example, in La petite Fadette, a clever little girl called 
litte Fadette, faced with contempt and misunderstanding, she never loses her optimistic and open character. In the end, she manages to win the love of Landré. In La mare au diable, little Marie is a young shepherdess, who is pure, honest and kind. Poverty cannot destroy her courage. She finally gets married with the man of her heart. In François le Champi, Madelaine is described as a tender, pure and benevolent woman. Her husband abuses her, poverty and debts weigh on her shoulders. But thanks to the help of Francis, she gets rid of the painful life and finally gets married with this nice man. These embellished characters, plus the backdrop of beautiful nature, constitute a magnificent text of George Sand's optimistic romanticism.

Of course, it doesn't mean that there's only bright side in the works of George Sand. Just like a painting, besides the bright side, there's also dark side in her novels. For example, François le Champi reflects the serious problem of child abandonment in the countryside. But the benevolence of these characters and the happy ending of these novels mitigate these dark sides. The optimistic romanticism of George Sand is sweet, but she does not lack passion to animate the will and the courage to revolt against destiny.

\section{Feminism}

Men are encouraged to fulfill their dream and to pursue their happiness, but women do not equally have the right. George Sand is a woman who has the courage to say no to this social inequality. During her childhood in Nohant, she already had a strong personality. Her vitality and originality scandalized the neighborhood: dressed as a man, she traveled the countryside on horseback, making friends and intellectual discussions. At the time when divorce was rare, she was already resolved to divorce herself with her husband to end her loveless marriage. And then she left her hometown to go to Paris, where she raised her children herself by the remuneration for her articles. In writing, she found moral and financial independence, and in her sentimental, demanding and restless life, she found liberation from the unworthy bonds of marriage. She smoked, dressed like a man, and enjoyed the love of many lovers. In a word, she had a really stubborn and indocile personality, just like a "hermaphroditic" genius, who united the vigor of man with the grace of woman. With the influence of her experiences and her character, the sprout of feminism is conceived in George Sand's pastoral trilogy, which reveals her ideas against the current. When her heroines treat problems of love and marriage, they overcome their shyness, decide to get rid of shackles of traditional morality and courageously pursue their happiness. It's a reflection of feminism on the literary level of George Sand.

\subsection{No Need for a Marriage without Love}

In La mare au diable, George Sand expresses her idea about marriage through a very simple love story. Germain is a widower aged twenty-eight. After the death of his wife, his father-in-law introduces a rich peasant woman from the neigh- 
boring village and persuades him to go and visit her with gifts. He takes his son Petit-Pierre, and Marie, a poor girl that he has to accompany to the farm where she's engaged as a shepherdess. But halfway through, because of the darkness and the fog, they go astray and they are forced to spend the night near "la mare au diable", unaware that the locals attribute to it an evil power. During the night, they get to know each other. Germain is touched by the purity and benevolence of this girl. He thinks she's the woman of his heart. He tells her shyly that he wants to marry her, but she does not seem to want to think about it. Petit-Pierre, more decided, has already taken her for mother ... At first the poor shepherdess does not dare to accept Germain, but afterwards she realizes the sincerity of love and finally accepts it courageously. Here, George Sand arranges a happy-ending for the heroine, to convey a message to readers, especially women, that they do not need to remain passive, that they should face the real feeling of their heart. Love is the basis of marriage. According to George Sand, the most unethical and unreasonable is not the kind of extramarital union based on true love and unacceptable to society, but the legal marriage without love [3].

\subsection{A Bold Choice Facing Ethical Judgement}

The story of François le Champi is more complex than La mare au diable, the thought expressed in this tale is also more rebellious. A woman named Madeleine, she adopts François le Champi who is nine years younger. She treats him like her son, but suffers the misunderstanding of other people, even of her husband. For the reputation of this woman of good heart, François leaves her and goes to live abroad. Several years later, he earns his reputation and his position through his efforts. When he returns to his hometown, he finds that Madeleine's husband is already dead, leaving lots of debts on her shoulders. She's living a painful life. With the help of François, Madeleine gets rid of the difficult situation. François has already fallen in love with Madeleine. In the end, they break the chains of traditional social conventions, get married and live happily together. Compared with La mare au diable, this novel touches the deeper level: ethics and morality. In the face of sincere love, disregarding the age and financial distance, can we accept love that contravenes ethical principles? For George Sand, it doesn't matter. Love conquers everything.

A more rebellious personality is revealed in François le Champi, interpreted by two points that question traditional ethics: firstly, the woman François falls in love with is already married, and then, she's nine years older than him. It's unacceptable at that time; secondly, the feeling between Francois and Madeleine is transformed from affection between son and mother. In the eyes of people of that time, it's a moral depravity. However, George Sand attenuates and even neglects these two conflicts by light touches. The first difficulty is solved by the death of Madeleine's husband. As for the second, it seems that in the end, all the inhabitants of the village accept the reality in an open and quiet way.

George Sang despises male-centered culture, which imposes spiritual shackles 
and codes of conduct on women. She advocates the morality of humanity to counter the morality of social customs [4]. Madeleine is a typical figure who represents most French women in countryside in the 19th century. She's sweet, kind, hardworking, supports her husband in silence. Even a woman so traditional can accept love that deviates from orthodoxy, not to mention others.

\subsection{The Right to Pursue Happiness}

As for La petite Fadette, the character of the heroine is different from the other two rustic novels. Marie and Madeleine are typical examples of women in the countryside, but little Fadette is mischievous like a little boy, likes to do the wrong trick, she's called "la petite sorcière" [5], it means "the little witch". She leaves a bad impression on the inhabitants of the village. At first, like the others, Landré has no good feeling for her. On the contrary, he likes another girl. But after contacts by chance, he found that little Fadette also has merits. She's good in her heart. Little by little, Landré is attracted and fell in love with this girl with a strong personality. In fact, for Fadette's part, she has a crush on Landré for a long time. All she does is to attract the attention of Landré. In the end, Fadette, a poor and despised girl, succeeds in keeping love with Landré, a handsome boy who's rich and respected, with an unshakeable resolution.

George Sand's pastoral trilogy is full of clear and happy atmosphere. It's like an ode singing the praises of women. Her words encourage women to pursue their happiness, reverse the traditional destiny of women's roles.

\section{Love}

The contacts with utopian socialists in the 30 s and 40 s give George Sand's thoughts a color of utopia that tends to create good relations in the world, clear the obstacles between people, shorten the distance of any form, like the financial situation, social class, age, ethical and moral notions, etc. In her works, love has the power to achieve this goal.

In La mare au diable, the wealthy Germain prefers to marry Marie, a poor shepherdess, and Marie finally removes her hesitations on the difference of age; in La petite Fadette, a handsome, rich and respected boy does not take into account the opposition of his parents and the attack of social public opinion, he conceives a firm love with a naughty, poor and despised girl; in François le Champi, there's not only the obstacle of the social layer, but also the gap of age and deep-rooted ethical and moral notions. Through love, they end up with overcoming all these obstacles. The power of love has changed the relationship between people, and even the spirit and personality of the character. Because of contempt and mockery for a long time, little Fadette has a bad habit of quarreling. But since she gets the friendship and love of Landré, this rough girl quickly becomes kind and graceful. It's the same thing for Silvain, the brother of Landré. Spoiled by his parents, he only knows how to love himself. Very sensitive, he has a melancholy temperament. Fadette aims at the origin of Silvain's psychological 
illness, criticizes his egoism, and teaches him to love others but not only himself. Little by little, Silvain becomes a selfless man who has a firm will.

In short, it is love that reigns George Sand's rustic novels. Love has great strength, makes a great influence. George Sand makes us believe that love is able to unite people who come from different social strata and thus establish an ideal world.

\section{Democracy}

In George Sand's pastoral trilogy, she describes the simple and honest character of peasants with a positive attitude, but criticizes the corrupt bourgeoisie with a negative attitude. She shows her clear love and hate.

The ideal rural life described by George Sand deserves approval, because peasants are not the bourgeois who come to the countryside for pleasure because of the boredom of epicurean life, on the contrary, they represent the workers in opposition to the bourgeoisie and the bourgeois customs. So, in a sense, the characterization of George Sand shines with democracy.

At the same time that George Sand describes pure and simple characters unpolluted by capitalism, she describes bourgeois and bourgeois customs in a criticized way. For example, in François le Champi, which "has the most literary values among her rustic novels" [6], she denounces problems in the countryside under the system of capitalism, makes descriptions of the gap between the rich and the poor. In her rustic novels, the negative characters are often rich or those who lend money at a usurious rate, like the mistress of the boss of the mill in François le Champi, the rich woman in La petite Fadette, the rich widow of the neighboring village in La mare au diable, etc. By comparison between selfish, corrupt, arrogant, vulgar bourgeois and hardworking, poor, honest, simple peasants, George Sand shows her love and hatred, as well as her criticism of the reality of capitalism.

George Sand's attitude towards the bourgeois and peasants is typically colored by Rousseau's thoughts. In her pastoral trilogy, she's in tune with Rousseau's ideas in Discours sur Porigine des unegalite par les hommes. She claims that the more corrupt and shameless society becomes, the more pure and passionate the yearning for rural life will be. According to her, in terms of psychological activity, peasants are more natural and better than excellent poets, Léon Cellier says in the preface of La mare au daible: "poetry originated from the people. Man is a born poet, and in order to renew the poetry, it's good to return to the source of people" [2]; in terms of real life, it's not difficult for them to lead a simple, peaceful, hard-working and liberal life. It's true that George Sand has the conscience of criticizing the society of capitalism, and she also has the strong feeling of democracy, but her ideal life is that of small private owners, this is her biggest limit.

In her works, George Sand knows how to avoid the bitterness of positive characters. She often arranges a surprise fortune for them. For example, Fadette 
receives the inheritance of her grandmother, François gets financial help from his mother, etc. Thus George Sand establishes her dreaming rural life absolutely on the petty-bourgeois ideal. So, like Rousseau, she reflects the opinions and the interests of small private owners. She does not represent the will of the proletariat.

\section{Conclusion}

By analyzing La mare au diable, La petite Fadette and François le Champi, we found that George Sand's pastoral trilogy brings together Rousseau's thought, optimism, feminism, love and democracy; her rustic novels are full of good aspirations. Although there's often a gap between her heroes and heroines, she's always able to mitigate or even remove these differences to unite them by the force of love, thus showing us an ideal world. There's no sorrow or groan in her pastoral trilogy; there's only joy from the deepest heart. The picturesque landscape of nature, the fresh country air, the courage to overcome obstacles, and the grandiose love, constitute a romantic countryside fairy tale. Her fresh style, as well as her independent and indolent character, has a great influence on readers from her time to the present day. This paper is only a preliminary analysis and summary of George Sang's pastoral trilogy, and it's not deep enough in the study on the details of her works. All that precedes is only a dim light of the abundant work of George Sand. She deserves more in-depth studies.

\section{Conflicts of Interest}

The author declares no conflicts of interest regarding the publication of this paper.

\section{References}

[1] Zhang, N. (2004) Tragic Transcendence of Female Literature: On literary works of George Sand. Journal of Jiangsu Administration Institute, 6, 118-121.

[2] Sand, G. (1973) La mare au diable. Flammarion, Paris.

[3] Liu, M.J. (2007) History of French Literature. People's Literature Publishing House, Beijing.

[4] Liu, H.Y. (2005) George Sand and Women's Consciousness. Journal of Hunan University of Science and Engineering, 2, 180-182.

[5] Sand, G. (2016) La petite Fadette. Flammarion, Paris.

[6] Huang, X.C. (2005) Unique Originality of François le Champi. Journal of Sichuan International Studies University, 4, 31-36. 